\title{
SILVER-NANOPARTICLES MODIFIED SOFT LINER MATERIAL FOR OBTURATOR WEARERS WITH ACQUIRED PALATAL DEFECT. MICROBIOLOGICAL CROSSOVER STUDY
}

\author{
Radwa M.K. Emera*, Ahmed K. Khalifa** and Noha Nabil Sheta***
}

\begin{abstract}
Aim: This research aimed to clinically investigate the microbecidal power of silver nano-particles modified autopolymerized soft lining material for acquired palatal defect obturator wearers.

Materials and methods: A total of sixteen patients with acquired palatal defect were selected from the Mansoura Oncology center and referred to the Removable Prosthodontics Department, Faculty of Dentistry, Mansoura University. For each patient, immediate surgical obturator was constructed and then replaced by temporary obturator two weeks after the surgery. At definitive abturator construction, random assigning of patients into two equal groups (eight patients each) was done. Within patient cross over study design was followed with respect to silver nanoparticles (AgNps) percentages added to the self-cure soft liner material where: Patient's obturators in group I were lined with untreated soft liner followed by modified soft liner with $0.05 \%$ loading by weight of $\mathrm{AgNps}$ added to $5 \mathrm{gm}$ of the polymer powder followed by modified soft liner with $0.2 \%$ loading by weight of $\mathrm{AgNps}$ for one month of each soft liner application. In group II the sequence was reversed. Microbiological investigation was performed to identify bacterial colonization count related to different soft liner samples.
\end{abstract}

Results: The highest mean of bacterial count was recorded with the soft liner samples without AgNps additives $\left[\right.$ mean $\left.=(762.5 \pm 85.08) \times 10^{3}\right]$; while the lowest mean recorded with soft liner with $0.2 \% \mathrm{AgNps}$ by weight $\left[\right.$ mean $\left.=(0.634 \pm 0.73) \times 10^{3}\right]$. (ANOVA) test indicated a significant reduction in bacterial count within increased $\mathrm{AgNps}$ concentration. Wilks' lambda $=0.14, \mathrm{f}=40.75$ and $\mathrm{p}=0.001$.

Conclusions: Within parameters of this study, it could be concluded that: Modification of autopolymerized acrylic-based soft liner with $\mathrm{AgNps}$ is a simple reliable method to enhance its bactericidal activity especially for obturator wearers. The antimicrobial efficacy of AgNps modified soft liner seemed to be concentration dependent.

KEYWORDS: Silver nano-particles, soft liner, obturator

\footnotetext{
* Associate Professor, Department of Prosthodontics, Faculty of Dentistry, Mansoura University, Mansoura, Egypt

** Lecturer, Department of Prosthodontics, Faculty of Dentistry, Mansoura University, Mansoura, Egypt

*** Lecturer, Department of Biomaterials, Faculty of Dentistry, Mansoura University, Mansoura, Egypt
} 


\section{INTRODUCTION}

Greater incidence of oral fungal infection was confirmed in cases received therapy for cancer. Chemotherapy and radiotherapy to head and neck region were accompanied by a seriously higher risk of oral fungal infections. This increased risk in patients receiving radiation therapy may be caused by diminished salivary secretion. ${ }^{(1)}$

Additionally, clinical observations as well as preliminary investigations demonstrated post-surgical symptoms of defect inflammation caused by Candida strains usually occurring in cases of resected maxillary tumor who wear obturators to eliminate the passage between oral and nasal cavities. In these cases, the initiation of this pathological condition is accompanied by the adherence of pathogenic microorganisms to prosthesis contacting tissues. The contact affects proliferation of fungi both on the mucosa and on the prosthetic devices. ${ }^{(2,3)}$

Soft lining materials are used to engage inaccessible undercuts, improve obturator retention and provide a cushion for soft tissues. There are numerous reports on soft lining materials being colonized by yeasts. ${ }^{(4,5)}$ Accordingly, maintenance of soft liners and the prevention of colony formation by microorganisms are important for oral tissue health. ${ }^{(6)}$

Soft lining materials that possess antibacterial properties are preferred in use for obturators. (7) Nano-particles that possess antimicrobial activity are of significant respect in the development of bactericidal materials.$^{(8)}$ Modification of soft linings materials by silver nanoparticles (Ag NPs) can be an improvement in that respect. Fungicidal and bactericidal properties of silver have been known for centuries and they have been scientifically proved. ${ }^{(9,13)}$

Silver nanoparticles showed antimicrobial effects as additives in irreversible hydrocolloid impression materials, ${ }^{(14)}$ denture base acrylic resins, ${ }^{(15)}$ tissue conditioners $^{(16)}$ and Silicon soft lining materials. ${ }^{(17)}$
Consequently, addition of AgNps into acrylicbased soft liners to modify their bactericidal effect was introduced. Recent in-vitro studies have proved the antifungal effect of nanosilver modified heatcure acrylic-based soft denture liner ${ }^{(18)}$ and self-cure soft liner that showed a respectable antimicrobial effect. ${ }^{(19)}$ Therefore, this research aimed to clinically investigate the microbecidal power of silver nanoparticles modified self-cure soft lining material for acquired palatal defect obturator wearers.

The null hypothesis is no change in the bacterial count with different concentration of AgNps additives will be observed within the same patient.

\section{MATERIALS AND METHODS:}

A total of sixteen patients were selected from the Mansoura Oncology center and referred to the Removable Prosthodontics Department, Faculty of Dentistry, Mansoura University. They belong to both sexes (10 males, 6 females) and their ages ranged from 55 to 70 years $($ mean $=63 \pm 7.3)$. Patients had either partially or completely edentulous arches with acquired palatal defect caused by resection of neoplastic lesion while the mandibular arches were intact partially or completely edentulous ones (Fig. 1). This research work was approved by the Faculty Ethical Committee under code number (1603-12).

After informing the patients about the treatment plane and their follow-up program, immediate surgical obturator was constructed and then replaced by temporary obturator two weeks after the surgery.

The patients were checked every 2 weeks for inspection of the defect tissues during wound healing and for the replacement of tissue conditioner lining of the obturators. After the complete healing approved by the oncologist, definitive obturator was constructed for each patient as follows

- Patient was seated in the upright position. Maxillary and mandibular hydrocolloid (CA 37. 
Superior pink, cover, Holand bv) Impressions was poured in dental stone (Microstone ${ }^{\circledR}$, USA)

- Maxillary and mandibular autopolmerizing acrylic resin (Acrostone, Egypt) custom trayes were constructed.

- Design of the obturator metallic/acrylic frame work for pateints with maxillary partially edentulous arches was planned followed by making the needed mouth prepartions.

- For making the maxillary final imression, the custom tray was used to record final silicon impression after blocking of undesirable soft tissue undercuts in the resected side with a piece of gauze that was tied with a thread and lubricated with Vaseline. Impressions poured in dental stone .

- Wax pattern of the fram works of maxillary partially edentulous arches was constructed on the duplicated modified master casts, cast into cobalt chromium alloy, finished, polished and tryed intraoral.

- Bite blocks were constructed followed by recording of maxillo-mandibular relation. Mounting on semi-adjustable articulator (Dentatus international, Arts, Hagertsen, Sweeden) was done and non-anatomic acrylic resin artificial teeth (Acrostone ${ }^{\mathrm{TM}}$, Egpyt) were arranged for harmonized occlusion.

- Obturators were processed into heat-cure acrylic resin following hollow pulp obturator technique, finished and polished (Fig.2).

- Verification of obturators was done intraoral, pressure areas of polished surfaces and borders were evaluated using pressure indicating paste. Bulb portion was checked by custom made pressure indicating paste.

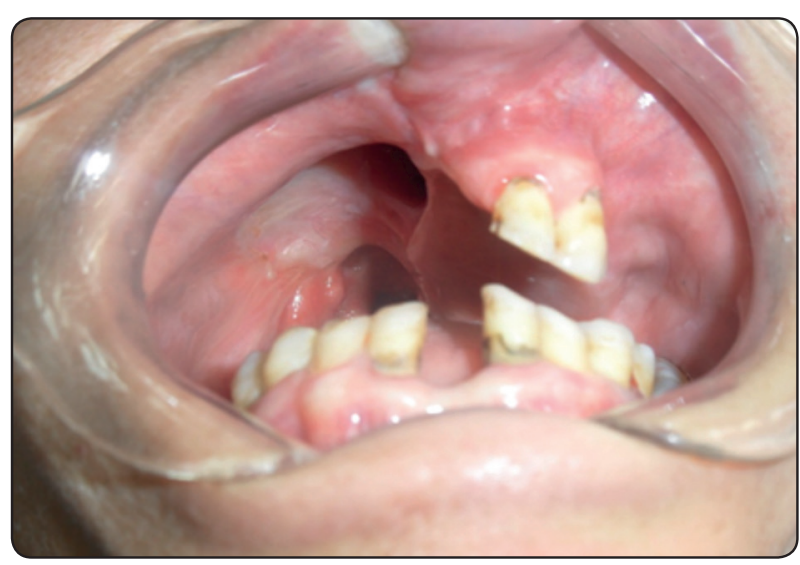

Fig. (1) Partially edentulous maxillary arch with acquired palatal defect.

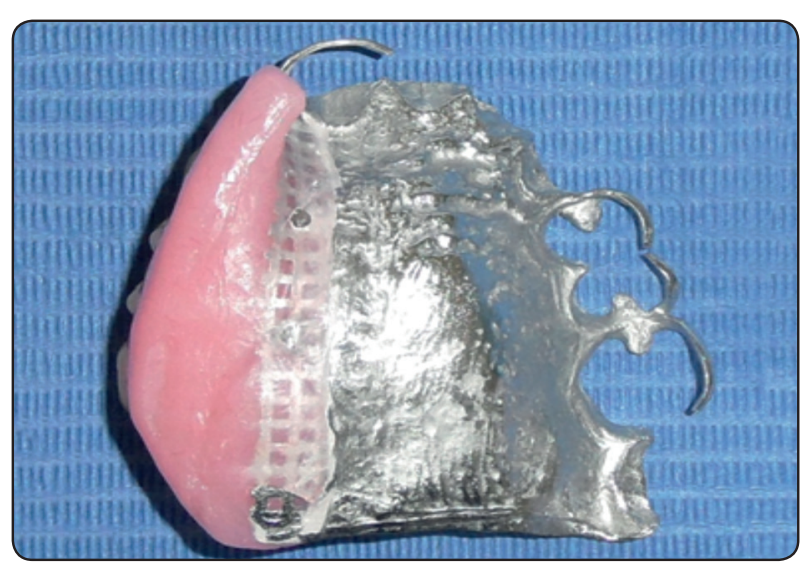

Fig. (2) Finished definitive obturator.

\section{Patients grouping:}

Random assigning of patients to two equal groups (eight patients each) was done through computerized randomization to ensure comparability of the two groups.

Within patient crossover study design was followed with respect to silver nanoparticles (AgNps) (SigmaAldrich CO., USA) percentages added to the acrylic based autopolymerized soft liner material (Acrostone, Egypt), where:

Patient's obturators in group I were lined with conventional soft liner. After one month, the liner was replaced by a soft liner modified by adding $0.05 \%$ by weight of $\mathrm{AgNps}$ added to $5 \mathrm{gm}$ of the polymer powder. After a month later the soft liner 
was removed and a new layer of liner modified by adding $0.2 \%$ by weight of $\mathrm{AgNps}$ added to $5 \mathrm{gm}$ of polymer powder was applied. In group II the sequence was reversed beginning with $0.2 \% \mathrm{AgNps}$ additive to the soft liner followed by $0.05 \% \mathrm{AgNps}$ additive to the soft liner and finally the conventional soft liner (Fig. 3, 4).

This study design was conducted to ensure that each patient would serve as a control for him/ herself and eliminate any suspicious cumulative effect of AgNps added to the soft liner material. - Soft liner was mixed according to manufacture instructions, applied on the obturator pulp surface

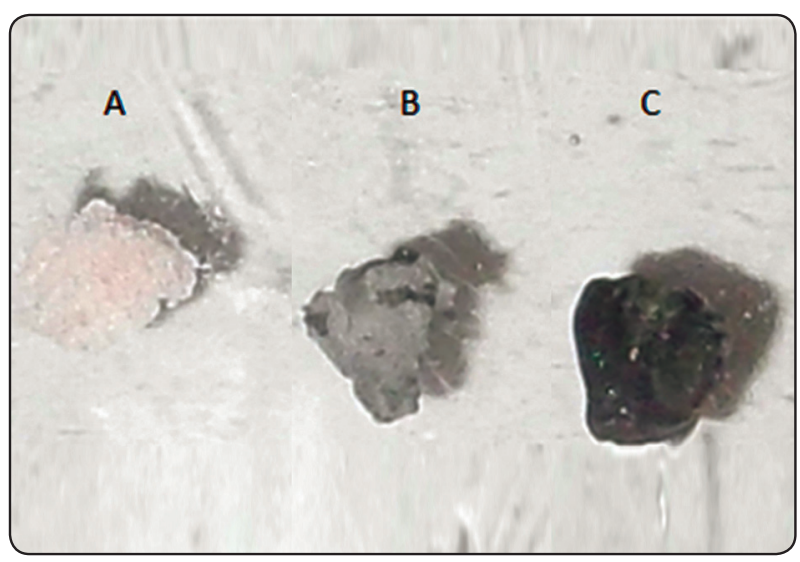

Fig. (3) samples of the soft liner with $\mathrm{AgNps}$ additives with $0 \%$ (A), with 0.05 (B) and $0.2 \%$ (C)

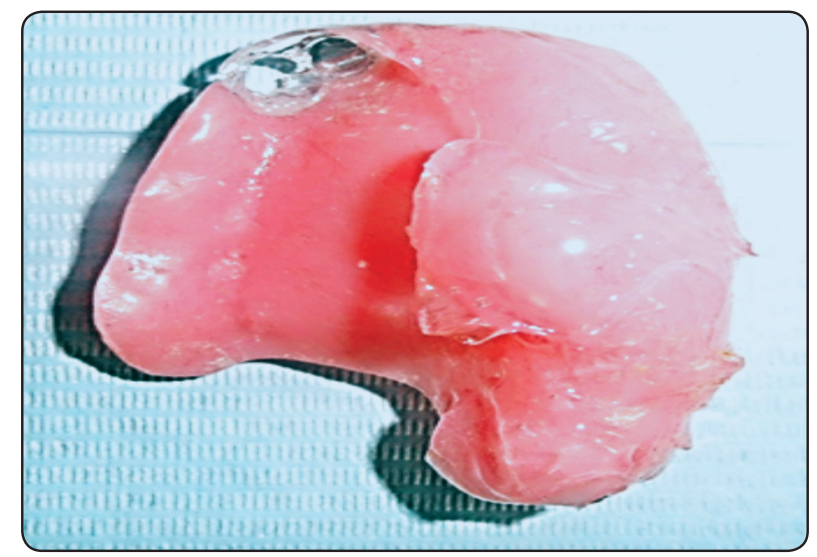

Fig. (4) Applied soft liner on the intaglio of obturator after intraoral application and allowed to set under guidance of the obturator adaptation to non-resected side. All patients were instructed for proper oral hygiene measures and regular periodic recalls for maintenance and evaluation.

\section{Microbiological examination:}

Soft liner samples were collected for each patient after one month of each studied soft liner application.

\section{Microbilogical specimen collection:}

- Circular standardized diameter samples of soft liner were prepared using trephine bur.

- Samples were kept in sterile nutrient broth tubes and transferred immediately to the microbiology laboratory, Faulty of Medicine, Mansoura University.

\section{Bacterial culture:}

- Vials containing the soft liner samples were vortexed for 2 minutes to release bacteria then centrifuged for 5 minutes to help bacterial concentration.

- One microliter of the centrifuged solution was obtained by a pipette and plated on blood agar media in semiquantitative manner, then incubated at $37 \mathrm{c}^{\circ}$, for 48 hours.

- After bacterial culturing, identification of isolated bacteria was carried out according to standard protocols ${ }^{(20)}$.

- The bacterial growth is represented in the form of $\mathrm{CFU} / \mathrm{mL}$

\section{RESULTS}

Due to the large reading numbers, all resulted readings were subdivided by 1000 .

From the resulted date, the highest mean of bacterial count was recorded with the soft liner 
without AgNps additives (mean $=762.5 \pm 85.08$ ); while the lowest mean was recorded with modified soft liner with $0.2 \%$ AgNps by weight (mean = $0.634 \pm 0.73$ ) (Table 1). (Fig. 5)

A one way repeated measured analysis of variance (ANOVA), was conducted to evaluate the null hypothesis that there is no change in the bacterial count within different concentration of AgNps additives within the same patient $(\mathrm{N}=16)$.
The results of the ANOVA indicated a significant reduction in bacterial count within increased $\mathrm{AgNps}$ concentration. Wilks' lambda $=0.14, \mathrm{f}=40.75$ and $p=0.001$. Thus, there is a significant evidence for null hypothesis rejection.

The comparison proved that each pairwise difference was significant $(p=0.001)$. There was a significant decrease in bacterial count within increased AgNps concentration in soft liner. (Table 2)

TABLE (1) Descriptive statistic for the bacterial count within different AgNP concentrations

\begin{tabular}{|c|c|c|c|c|}
\hline \multirow{2}{*}{ AgNp Conc. } & \multirow{2}{*}{ Mean } & \multirow{2}{*}{ Std. Error } & \multicolumn{2}{|c|}{$95 \%$ Confidence Interval } \\
\cline { 3 - 5 } & & & Lower Bound & Upper Bound \\
\hline $0 \%$ & 762.500 & 85.086 & 581.144 & 943.856 \\
\hline $0.05 \%$ & 3.188 & .390 & 2.357 & 4.018 \\
\hline $0.2 \%$ & .634 & .073 & .479 & .790 \\
\hline
\end{tabular}

All readings are subdivided by 1000

TABLE (2) Pairwise Comparisons within subject for the bacterial count with different AgNP concentrations

\begin{tabular}{|c|c|c|c|c|c|c|}
\hline \multirow{2}{*}{ (I) conc } & \multirow{2}{*}{ (J) conc } & \multirow{2}{*}{$\begin{array}{c}\text { Mean } \\
\text { Difference (I-J) }\end{array}$} & \multirow{2}{*}{ Std. Error } & \multirow{2}{*}{ Sig. ${ }^{b}$} & \multicolumn{2}{|c|}{ 95\% Confidence Interval for Difference ${ }^{b}$} \\
\hline & & & & & Lower Bound & Upper Bound \\
\hline \multirow{2}{*}{$0 \%$} & $0.05 \%$ & $759.313^{*}$ & 84.895 & .000 & 530.628 & 987.997 \\
\hline & $0.2 \%$ & $761.866^{*}$ & 85.069 & .000 & 532.713 & 991.019 \\
\hline \multirow{2}{*}{$0.05 \%$} & $0 \%$ & $-759.313^{*}$ & 84.895 & .000 & -987.997 & -530.628 \\
\hline & $0.2 \%$ & $2.553^{*}$ & .410 & .000 & 1.449 & 3.657 \\
\hline \multirow{2}{*}{$0.2 \%$} & $0 \%$ & $-761.866^{*}$ & 85.069 & .000 & -991.019 & -532.713 \\
\hline & $0.05 \%$ & $-2.553^{*}$ & .410 & .000 & -3.657 & -1.449 \\
\hline
\end{tabular}

Based on estimated marginal means

*. The mean difference is significant at the .05 level.

b. Adjustment for multiple comparisons: Bonferroni.

All readings are subdivided by 1000

Fig. (5) bar chart for bacterial count with different AgNps concentrations

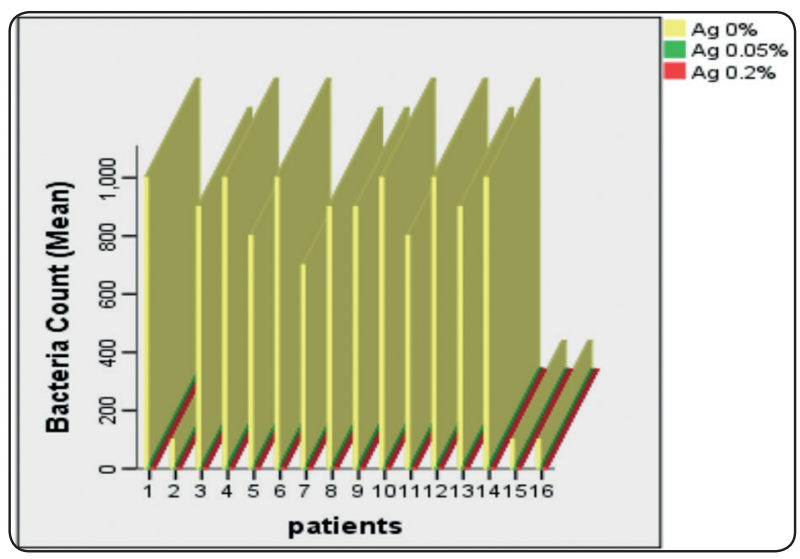




\section{DISCUSSION}

Several studies confirmed the ability of Candida species especially Candida albicans to adhere to acrylic prostheses (Polymethyl methacrylate); this capability subjects a number of patients to medical complications requiring a long treatment coarse for candidiasis ${ }^{(21,22)}$, and can lead to serious infections with a high rate of mortality ${ }^{(23)}$.

Obturator wearers with oro-nasal communication often present prosthesis-induced stomatitis. The higher rate of Candida albicans colonization on the acrylic nasal surfaces must be considered as a serious matter because it is directly related to the nasal floor and adds to the nasal cavity contamination (24). Adhesion of microbes on biomaterials surface relays on composition of biomaterials ,the surface structure, as well as on the physic-chemical properties of the bacterial cell membrane; so that, AgNps, have been proposed as antimicrobial agents in polymeric materials ${ }^{(25-28)}$.

Consequently, in this research AgNps were introduced into soft liner of obturator as an attempt to enhance its bactericidal activity against Candida albicans and other microbial species which are the main predisposing factors of mucosal inflammation. The percentages of $\mathrm{AgNps}$ used in this study $(0.05 \%$ and $0.2 \%$ by Wight) were proven to decrease water sorption, and have no influence on shear-bond strength of the acrylic-based soft liner material ${ }^{(18)}$.

Results of this work indicated a statistically high significant decrease in Candida albicans colony formation (units $/ \mathrm{ml}$ ) after modification of the soft liner with AgNps. The bactericidal activity appeared to be concentration dependent.

This result could be attributed to the fact that incorporating $\mathrm{AgNps}$ into soft liner powder particles decrease their surface free energy, the interaction between cohesion forces that determine if wetting will occur or not, resulting in decreased possibility of microbial adhesion. This explanation is consistent with Dwairi et al, ${ }^{(29)}$ who reported that; the more the free surface energy, the more will be the adhesion of micro-organisms and alternatively, the more hydrophobic is the surface, the less adherence of cells is predicted.

After one month, it was found that all micobial species disappeared in case of soft liner modified with AgNps with the higher concentration $(0.2 \%)$. This finding can be attributed to the role of freeing silver $(\mathrm{Ag}+)$ ions from nano-silver and its toxicity towards micro-organisms. ${ }^{(30)}$ The potential effect of nano-silver depends on its role as a source of $\mathrm{Ag}+$ ions. ${ }^{(31)}$ Miao et al. ${ }^{(32)}$ refereed the effect of nano-silver to the dissolved $\mathrm{Ag}+$ ions toxicity. Thus the higher concentration of AgNps added to the soft liner material within the accepted biologic parameters, the more release of $\mathrm{Ag}+$ ions and in turn the higher bactericidal effect.

However, some researches concluded that the antimicrobial effect was obtained from direct contact killing action; not due to $\mathrm{Ag}+$ ions leached out of the copolymer. ${ }^{(33-35)}$ The metallic nano-particle size offers a significant large contact surface area of particle to the micro-organisms commensals ${ }^{(22)}$.

Previous researches were conducted to examine release of silver from a variety of polymeric materials, and a number of them concluded that the bactericidal effect of AgNps was obtained through its direct contact to microorganisms. ${ }^{(36,18)}$ However, this was disagreed by some studies where different silver release concentrations were detected..$^{(37-39)}$ This controversy may be explained by differences in polymeric materials types and their methods of polymerization, in addition to the differences in techniques of $\mathrm{AgNps}$ incorporation.

\section{CONCLUSIONS}

Within parameters of this study, it could be concluded that:

1- Modification of acrylic-based soft liner with AgNps is a simple method to enhance its bactericidal activity for obturator wearers.

2- The antimicrobial efficacy of AgNps modified soft liner seemed to be concentration dependent. 


\section{RECOMMENDATIONS}

1- Longer term clinical studied are still recommended to evaluate the cumulative effect of AgNps on oral mucosa.

2- It is recommended to study the effect of nanoparticles of other metals to modify soft liners antimicrobial activity.

\section{ACKNOWLEDGMENT}

The authors deeply thank all the staff members in the Department of Microbiology, Faculty of Medicine, Mansoura University for their technical assistance and support in this study.

\section{REFERENCES}

1. Nicolatou-Galitis O, Sotiropoulou-Lontou A, Velegraki A, Pissakas G, Kolitsi G, Kyprianou K, Kouloulias V, Papanikolaou I, Yiotakis I, Dardoufas K. Oral candidiasis in head and neck cancer patients receiving radiotherapy with amifostine cytoprotection. Oral Oncol 2003;39: 397-401.

2. Williams DW, Lewis MA. Isolation and identification of Candida from the oral cavity. Oral Dis 2000; 6: 3-11.

3. Więckiewicz W, Baran E, Zeńczak-Więckiewicz D , Proniewicz A. Fungi Inhabiting the Oral Mucosa and Soft Material Lining the Obturator of Intraoral Post-surgical Prosthesis. Kor J Med Mycol 2002;7(4): 201-8.

4. Borlase G. Use of obturators in rehabilitation of maxillectomy defects. Ann R Australas Coll Dent Surg. 2000: 15: 75-9.

5. Hegazy s, fouad M, Khalifa A. Two implants retained versus soft liner retained maxillary obturators in maxillary edentulous patients with unilateral maxillary defects (comparison of retention) J Dent Impl. 2013; 3(1): 29- 34.

6. Sangeorzan JA, Bradley SF, He X, Zarins LT, Ridenour GL, Tiballi RN, et al. A comprehensive study of Candidaspecific antibodies in the saliva of human immunodeficiency virus-positive individuals with oropharyngeal candidiasis. J Infect Dis 2002; 185:1269-76.

7. Sharon Anat, Atar-Froyman L, Beyth, N.; Weiss E. I, Sela, M, Jerusalem IL: The Antibacterial Properties of Obturator Lining Materials, Incorporated with QuaternaryAmmonium Polyethylenimine Nanoparticles. 60th Annual Meeting of the American Academy of Maxillofacial
Prosthetics and the 10th Biennial Meeting of the International Society for Maxillofacial Rehabilitation. International Congress on Maxillofacial Rehabilitation Interdisciplinary Rehabilitation .Care for the Head and Neck Patient 2012. October 27-30.

8. Goffeau A. Drug resistance: the fight against fungi. Nature. 2008; 452(7187):541-542.

9. Yamauchi J. Antibacterial activity of silver ions implanted in $\mathrm{SiO} 2$ filler on oral streptococci, Dent. Mater. 1996, 12(4), 227-9.

10. Kawashita M, Tsuneyama S, Miyaji F, Kokubo T, Kozuka H, Yamamoto K. Antibacterial silver-containing silica glass prepared by sol-gel method, Biomaterials, 2000, 21(4), 393-8.

11. Syafiuddin T, Hisamitsu H, Toko T, Igarashi T, Goto N, Fujishima A. In vitro inhibition of caries around a resin composite restoration containing antibacterial filler, Biomaterials, 1997, 18(15), 1051-1057.

12. Yoshida K, Tanagawa M, Atsuta M. Characterization and inhibitory effect of antibacterial dental resin composites incorporating silver-supported materials, J. Biomed. Mater. Res., 1999, 47(4), 516-522.

13. Fan C, Chul L, Rawls HR, Norling BK, Cardenas HL, Whang K. Development of an antimicrobial resin - A pilot study, Dent. Mater. 2011, 27(4), 322-328.

14. Ginjupalli K, Alla RK, Tellapragada C, Gupta L, Perampalli NU. Antimicrobial activity and properties of irreversible hydrocolloid impression materials incorporated with silver nanoparticles. J Prosthet Dent. 2016;115(6):722-8.

15. Abdallad RM, Emera RM, Gebreil AS. Antimicrobial activity of silver nanoparticles and their effect on acrylic resin mechanical properties. E. D. J. 2015 Vol. 61(1): 1039-1052.

16. Nam K.In vitro antimicrobial effect of the tissue conditioner containing silver nanoparticles J Adv Prosthodont 2011; $3: 20-4$.

17. Chladek G, Mertas A,Barszczewska-Rybarek I, Nalewajek T, Żmudzki J, Król W , Łukaszczyk J. Antifungal Activity of Denture Soft Lining Material Modified by Silver Nanoparticles-A Pilot Study Int. J. Mol. Sci. 2011; 12, 4735-4744.

18. Issa MI, Abdul-Fattah N. Evaluating the effect of silver nanoparticles incorporation on antifungal activity and some properties of soft denture lining material J Bagh Coll Dentistry. 2015; 27(2):17-23 
19. Masallat DT, Omar NO, Khalifa AK, Emera RM. Microbicidal Power of Silver Nano Particles and its Benefit in Soft Liner Obturator Prosthesis. Egyptian Journal of Medical Microbiology. 2016; 25(4): 33-37

20. Koneman S. Color Atlas and Text Book of Diagnostic Microbiology: Winn W.J., Allen, S., Koneman,E., Procop, G., Schreckerberger, P. and Woods G. Lippincott, Williams \&Wilkins. 6TH ed.(2006).

21. Muñoz-Bonilla A, Fernández-García M. Polymeric materials with antimicrobial activity. Prog Polym Sci. 2012; 37(2):281-339

22. Nuñez-Anita RE, AcostaTorres LS, vilar-Pineda J, Martínezespinosa JC, De la FuenteHernández J, Castaño VM. Toxicology of antimicrobial nanoparticles for prosthetic devices. International Journal of Nanomedicine 2014:9 3999-4006.

23. Ten Cate JM, Klis FM, Pereira-Cenci t, Crielaard W, de Groot PWJ. Molecular and cellular mechanisms that lead to candida biofilm formation. J dent res 2009;88:105-115.

24. MattoS BS, alves de SouSa A, Helena C. G. de MaGalHãeS M, andré M, dIaS RB. Candida albicans in Patients with Oronasal Communication and Obturator Prostheses Braz Dent J (2009) 20(4): 336-340.

25. Acosta-Torres LS, López-Marín LM, Núñez-Anita RE, Hernández Padrón G, Castaño VM. Biocompatible metaloxide nanoparticles: nanotechnology improvement of conventional prosthetic acrylic resins. J Nanomater. 2011; 2011:941561.

26. Acosta-Torres LS, Mendieta I, Nuñez-Anita RE, CajeroJuárez M, Castaño VM. Cytocompatible antifungal acrylic resin containing silver nanoparticles for dentures. Int $\mathrm{J}$ Nanomedicine. 2012;7:4777-4786.

27. Elsaka SE, Hamouda IM, Swain MV. Titanium dioxide nanoparticles addition to a conventional glass-ionomer restorative: influence on physical and antibacterial properties. J Dent. 2011; 39(9):589-598.

28. Muñoz-Bonilla A, Fernández-García M. Polymeric materials with antimicrobial activity. Prog Polym Sci. 2012; 37(2):281-339

29. AL-Dwairi Z, AL-Quran F, AL-Omari O. The effect of antifungal agents on surface properties of poly (methyl methacrylate) and its relation to adherence of Candida albicans. Journal of Prosthodontic Research 2012;56:272-80.

30. Tolaymat TM, El Badawy AM, Genaidy A, Scheckel KG, Luxton TP, Suidan M. An evidence-based environmental perspective of manufactured silver nanoparticle in syntheses and applications: a systematic review and critical appraisal of peer-reviewed scientific papers. Sci Total Environ. 2010;408(5):999-1006.

31. Navarro E, Piccapietra F, Wagner B, Marconi F, Kaegi $\mathrm{R}$, Odzak N, et al. Toxicity of silver nanoparticles to Chlamydomonas reinhardtii. Environ Sci Technol. 2008;42(23):8959-64.

32. Miao A-J, Schwehr KA, Xu C, Zhang S-J, Luo Z, Quigg A, et al. The algal toxicity of silver engineered nanoparticles and detoxification by exopolymeric substances. Environ Pollut. 2009;157(11):3034-41.

33. Cao Z, Sun X, Sun Y, Fong H. Rechargeable antibacterial and antifungal polymeric silver sulfadiazines. J Bioact Compat Polym 2009; 24(4): 350-67.

34. Fabrega J, Fawcett SR, Renshaw JC, Lead JR. Silver nanoparticle impact on bacterial growth: effect of $\mathrm{pH}$, concentration, and organic matter. Environ Sci Technol. 2009;43(19):7285-90.

35. Kawata K, Osawa M, Okabe S. In vitro toxicity of silver nanoparticles at noncytotoxic doses to HepG2 human hepatoma cells. Environ Sci Technol. 2009;43(15):6046-51.

36. Monteiro DR, Gorup LF, Takamiya AS, de Camargo ER, Ruvolo Filho AC, Barbosa DB. Silver distribution and release from an antimicrobial denture base resin containing silver colloidal nanoparticles. J Prosthodont 2011; 21: 7-15.

37. Reidy B, Haase A, Luch A, Dawson K A, Lynch I. Mechanisms of silver nanoparticle release, transformation and toxicity: a critical review of current knowledge and recommendations for future studies and applications. Materials. 2013; 6: 2295- 350.

38. Furno F, Morley K S, Wong B, et al. Silver nanoparticles and polymeric medical devices: a new approach to prevention of infection. J Antimicrob Chemother 2004; 54:1019-24.

39. Kumar R, Munstedt $H$. Silver ion release from antimicrobial polyamide/silver composites. Biomaterials 2005; 26: 2081-8. 